\title{
MODELING THE DEMAND FOR HOUSEHOLD COOKING FUELS AND ASSESSING ENVIRONMENTAL EFFECTS IN A PERIURBAN AREA OF MADAGASCAR
}

\author{
Ralibera Andriamifidy Gerard ${ }^{1}$ \\ Researcher, \\ Energy Department, \\ National Center of Industrial and Technology \\ Researches. \\ Rakotosaona Rijalalaina ${ }^{2}$ \\ Professor, \\ Polytechnic Superior School of Antananarivo.
}

\author{
Andrianaivoravelona Jaconnet Oliva ${ }^{2}$ \\ Professor, \\ Polytechnic Superior School of Antananarivo.
}

\author{
Ramaroson Jean de Dieu ${ }^{1}$ \\ Professor, \\ Materials and Civil engineering Department, \\ National Center of Industrial and Technology \\ Researches.
}

${ }^{1}$ CNRIT, 38 Rue Rasaminanana, Fiadanana, 101 Antananarivo, Madagascar.

${ }^{2}$ ESPA, BP 566. Antananarivo 101. Madagascar.

Article DOI: https://doi.org/10.36713/epra2381

\begin{abstract}
This study is trying to look into the relationship between households' exploitation of ligneous resources for energy purposes and environmental problems, concerning a periurban area of Madagascar. The matter is threatening because households in developing countries will always depend on forest resources and environmental issues seem to be more and more complex. The main problems are associated with socio-economical, cultural, environmental, and technical factors, that is why it is complicated to find out the best way to manage the system. For this, two types of descriptive surveys including 60 questions were used to collect information and data on household behavior in terms of cooking fuel use and consumption. The population of the study consisted of 1,075 households and fuel retailers inside the studied area, also called The Municipality of Andranonahoatra. Then data collected were analyzed using both descriptive and inferential statistics. After that, fuel consumption was modeled, using a linear multiple regression method to calculate the demand of each class of household and the pollutant gas emissions throughout the supply chain, i.e., production, transport, and end-use. For pollutant gases emitted by each fuel, the standards and literature results are used. The values obtained will be compared with the national and international emission levels. Findings of the study show significant positive relationships between socio-cultural and financial factors, and cooking fuel consumption, including fuelwood, charcoal, and liquefied petroleum gas (LPG). As a result, the elaborated models have estimated the average amount of fuel consumption in the Municipality at $117 \mathrm{~kg} / \mathrm{capita} / \mathrm{year}$ of charcoal, $23 \mathrm{~kg} / \mathrm{capita} / \mathrm{year}$ of fuelwood, and $0.6 \mathrm{~kg} / \mathrm{capita} / \mathrm{year}$ of LPG. Form there, in the environmental field, each inhabitant emits about, $0.8 \mathrm{t}$ of $\mathrm{CO}_{2} /$ capita/year, $9 \mathrm{~kg}$ of $\mathrm{CH}_{4} /$ capita/year, $26 \mathrm{~kg}$ of Non-Methanic Volatile Organic Compounds (NMVOC)/capita/year, $7 \mathrm{~g}$ of $\mathrm{N}_{2} \mathrm{O} / \mathrm{capita/year}$ and $3.4 \mathrm{~kg} / \mathrm{capita} / \mathrm{year}$ of fine particles inhaled directly by the person preparing the meal. In other words, each person would prevent the sequestration of about $1.27 \mathrm{t}$ of $\mathrm{CO}_{2} /$ year. Using the Global Warming Potential, the emission is 1.1 tons $\mathrm{CO}_{2}$-equivalent/capita/year due to the use of cooking fuels. These models and assessments can help and incite governments and decision-makers to elaborate strategy aiming to protect the forest ecosystem while ensuring the energy supply of poor households in developing countries.
\end{abstract}

KEYWORDS: cooking fuels, model, greenhouse gas, global warming potential. 


\section{INTRODUCTION}

In Madagascar, like in most developing countries, the residential sector is among the most energy-intensive. The energy balance shows that the household sector accounts for more than $90 \%$ of the energy consumed [1]. This rate is due to the use of fuelwood and charcoal as primary fuels by $98.4 \%$ of households [2], and LPG in a very small quantity. This present paper is a logical continuation of the previous study which aimed to model the cooking fuel choice made by consumers, to classify them [3-4]. One can solve the problem by using aggregated data and directly evaluate fuel consumption, but it usually hides the inherent behavior associated with each class (Serrano-Medrano et al. 2013). Models and assessments presented in this paper attempt to reach the different phases of the household cooking fuel system, dealing with the demand side, supply chain, and environmental effects. The goal is to be able to effectively manage forest productivity, ensure the cooking fuel supply, and ultimately to preserve the local and global environment. Many researchers have already carried out works on urban household cooking energy choice and use in developing countries. And they attest that by 2050, the majority of urban households will still depend on charcoal if large-scale projects are not undertaken now.

\section{METHODOLOGY}

\section{Data and modeling}

The methodology used for demand modeling is based on two consecutive processes: first, identifying the exogenous and significant variables on which the consumption of fuelwood, charcoal, and LPG depends, for each household class. Then, the monthly per capita consumption per class of each fuel will be modeled by the multiple linear regression method. At first glance, this can be directly dealt with all the data, as a whole, to model aggregate demand, but to be more precise, disaggregated modeling of household behavior in terms of fuel consumption is processed for each class. Indeed, the fuel consumption of a household in class $\mathrm{i}$ is given by the following matrix $\mathrm{q}_{\mathrm{ij}}$ :

Where:

$$
\mathrm{q}_{\mathrm{ij}}=\sum\left(\mathrm{A}_{\mathrm{ij}} \mathrm{X}_{\mathrm{ij}}+\mathrm{C}_{\mathrm{ij}}\right)
$$

$\mathrm{X}_{\mathrm{ij}}$ : matrix of significant exogenous variables of fuel $\mathrm{j}$ for class $\mathrm{i}$.

$\mathrm{A}_{\mathrm{ij}}$ : model coefficient matrix for each element of $\mathrm{X}_{\mathrm{ij}}$.

$\mathrm{C}_{\mathrm{ij}}$ : matrix of the constants of the model corresponding to class $\mathrm{i}$ and fuel $\mathrm{j}$.

- $\quad$ i ranges from class 1 to 7, including the seven fuel combinations practiced by households.

- $\quad$ j ranges from 1 to 4, where: 1=charcoal; 2=fuelwood; 3=LPG; 4=electricity (electricity is just to distinguish classes).

Introducing the household size $(\mathrm{HH})$ and the weight $\mathrm{w}_{\mathrm{i}}$ of each class $\mathrm{i}$, the total consumption of fuel $\mathrm{j}$ of the entire Municipality will be:

$\mathrm{N}$ : total number of households.

$$
\mathrm{Q}_{\mathrm{j}}=\sum_{\mathrm{i}=1}^{7} \mathrm{~N} * \mathrm{w}_{\mathrm{i}} * \mathrm{HH}_{\mathrm{i}} * \mathrm{q}_{\mathrm{ij}}
$$

The environmental effect due to the use of each fuel $j$ will then be evaluated based on its quantity $Q_{j}$.

\section{Environmental issues}

\section{Deforestation}

Suppose $\mathrm{Q}_{\text {fuelwood }}$ and $\mathrm{Q}_{\text {charcoal }}$ the amount of wood used to produce respectively fuelwood and charcoal. Cleared area related to cutting trees are modeled as follows:

- For fuelwood,

Where:

$$
\mathrm{S}_{\text {fuelwood }}=\mathrm{Q}_{\text {fuelwood }} * \frac{1}{\mathrm{~d}} * \frac{1}{\mathrm{~V}_{\mathrm{com}}} * \mathrm{~h}
$$

$\mathrm{S}_{\text {fuelwood }}(\mathrm{ha})$ : forest cleared to produce the fuelwood consumed $\mathrm{Q}_{\text {fuelwood; }}$

$\mathrm{d}\left(\mathrm{kg} / \mathrm{m}^{3}\right)$ : wood density. Note that eucalyptus is the preferred type of wood for households (Author's survey, 2018).

$\mathrm{V}_{\text {com }}\left(\mathrm{m}^{3} / \mathrm{ha}\right)$ : wood production in terms of commercial volume;

h: wood moisture ratio.

- For charcoal,

Where:

$$
\mathrm{S}_{\text {charcoal }}=\mathrm{Q}_{\text {charcoal }} * \frac{1}{\mathrm{R}_{\text {carb }}} * \frac{1}{\mathrm{~d}} * \frac{1}{\mathrm{~V}_{\mathrm{com}}} * \mathrm{~h}
$$

$\mathrm{S}_{\text {charcoal }}(\mathrm{ha})$ : forest cleared to produce $\mathrm{Q}_{\text {charcoal}}$;

$\mathrm{R}_{\mathrm{carb}}$ : carbonization efficiency. According to the Food and Agriculture Organisation (FAO, 1983), Eucalyptus is a good woody material for producing charcoal.

\section{Pollutant gas emissions}

Like in deforestation, pollutant gas emissions will be assessed for each main phase of the three chains for each fuel. We will have:

Where:

$$
\mathrm{E}_{\mathrm{g}}=\sum_{\mathrm{j} ; \mathrm{p}=1}^{3} \mathrm{Q}_{\mathrm{jp}} * \mathrm{~F}_{\mathrm{gjp}}
$$


$\mathrm{E}_{\mathrm{g}}(\mathrm{kg}$ or $\mathrm{t})$ : amount of pollutant gas g emitted, which can be $\mathrm{CO}_{2}, \mathrm{CH}_{4}, \mathrm{NO}_{2}, \mathrm{~N}_{2} \mathrm{O}$...

$\mathrm{Q}_{\mathrm{jp}}$ (in $\mathrm{kg}$ ): flow of fuel $\mathrm{j}$ involved in phase $\mathrm{p}$ (production, transportation, and end-use) of the supply chain;

$\mathrm{j}$ varies from 1 to 3 and represents fuelwood, charcoal, and LPG;

$\mathrm{F}_{\mathrm{gjp}}$ : gas $\mathrm{g}$ emission factor of fuel $\mathrm{j}$ during phase $\mathrm{p}$.

\section{Emissions during charcoal production}

Charcoal production is processed by pyrolyzing wood in a kiln, also called carbonization. The volume of pollutant gas emitted depends on the wood species, the wood moisture ratio, the size of the pieces of wood to be carbonized, the wood preservation treatment, the heating speed, the final reaction temperature, the reaction atmosphere, the catalysts [5] and the type of kiln used. By adopting the raw formula of most wood $\mathrm{CH}_{\text {wood } 1.44} \mathrm{O}_{0.66}$ (Déglise 1980, Quirino 2000), as well as the distinction and rates defined by Bisu et al. [3], the wood contains mainly:

- Extracts in an average of $10 \%$, which are products from alive or dead cells;

- Lignin, $21 \%$ for leafy wood and $30 \%$ for resinous, and holocellulose $50 \%$;

- Ashes comprising mainly $\mathrm{Ca}, \mathrm{K}, \mathrm{Na}, \mathrm{Mg}, \mathrm{Si}, \mathrm{Fe}, \mathrm{P}$ oxides, in the order of $1 \%$ of the total mass and which may have a catalytic role in gasification reactions.

According to Lohri et al. (2016): "The pyrolysis gases are made up of condensable and non-condensable (permanent) parts. The condensable fraction, in liquid form, contains methanol $\left(\mathrm{CH}_{3} \mathrm{OH}\right)$, acetic acid $\left(\mathrm{CH}_{3} \mathrm{COOH}\right)$, steam $\left(\mathrm{H}_{2} \mathrm{O}\right)$ and tars. Non-condensable gases include $\mathrm{CO}_{2}, \mathrm{CO}, \mathrm{H}_{2}, \mathrm{CH}_{4}$ and other light hydrocarbons, as well as particles and more complex compounds such as polycyclic aromatic hydrocarbons (PAH). The exact combination of the compounds in the mixture depends on the original conditions of the raw material's pyrolysis process."

Carbonization occurs in a reductive environment and by a slowly increasing temperature up to a maximum of $600^{\circ} \mathrm{C}$ (slow pyrolysis) (Abbassi M. A. 2009; Daniel G., 2007). Déglise and Vernois (2015) and Déglise (1982) wrote that at $600^{\circ} \mathrm{C}$, therefore, it is the lignins that first decomposed into aromatic products such as vanillin, syringaldehyde, phenol, and cresol. Then, the methoxy- $\left(\mathrm{OCH}_{3}\right)$ groups of these products break down into methanol $\left(\mathrm{CH}_{3} \mathrm{OH}\right)$. After that, charcoal is obtained which origin is mainly lignin. As for hemicelluloses, they produce formaldehydes which in turn transform into $\mathrm{CO}$ and $\mathrm{CH}_{4}$. For celluloses, from $270^{\circ} \mathrm{C}$, a large part of the molecules is re-condensed to aggregate into charcoal. Besides, they produce formic acid and acetic acid that produce $\mathrm{CO}_{2}$ and $\mathrm{H}_{2}$ for the former, and $\mathrm{CH}_{4}$ and $\mathrm{CO}_{2}$ for the latter $[5]$.

\section{Table 1: Emitted gas during carbonization (in $\mathrm{g} / \mathrm{kg}$ of charcoal produced)}

\begin{tabular}{|c|r|r|r|r|r|r|r|r|r|}
\hline Gas & $\mathrm{CO}_{2}$ & $\mathrm{CO}$ & $\mathrm{CH}_{4}$ & NMVOC & TSP & IPC & Gas+TSP & $\mathrm{N}_{2} \mathrm{O}$ & $\mathrm{NO}_{\mathrm{x}}$ \\
\hline Quantity & 3,03 & 333 & 46.2 & 94.9 & 34.1 & 508 & 3,535 & 0.3 & 0.13 \\
\hline
\end{tabular}

TSP: Total Suspended Particles. ICP: Incomplete Combustion Products.

In this study we take a carbonization yield of $12 \%$ evaluated by the Gesellschaft für Internationale Zusammenarbeit (GIZ, 2014) to evaluate the quantities of gases emitted from the amount of charcoal produced, which supposed equal to the demand of the Municipality. The calculations will be made using the values set out in Table 1.

\section{Emissions during fuel transportation}

Concerning the transport of cooking fuels consumed by the Municipality, we assume that all of them are transported by road, and almost all vehicles are diesel-powered. Thus, to transport a given amount of a fuel $\mathrm{Q}_{\mathrm{j}}$, the amount of greenhouse gas (GHG) $\mathrm{g}$ emitted is given by the following equation:

$$
\mathrm{GHG}_{\mathrm{gj}}=\frac{\mathrm{Q}_{\mathrm{j}}}{\mathrm{M}_{\mathrm{j}}} * \mathrm{~d}_{\mathrm{j}} * \frac{\mathrm{L}}{100} * \mathrm{R} * \mathrm{~F}_{\mathrm{g}}
$$

Where:

$\mathrm{GHG}_{\mathrm{gj}}$ (kg of gas g): amount of gas g emitted per liter of diesel consumed to transport a quantity $\mathrm{Q}_{\mathrm{j}}$ of fuel $\mathrm{j}$;

$\mathrm{Q}_{\mathrm{j}}(\mathrm{kg} /$ year): amount of fuel $\mathrm{j}$ transported per year (see eq. 2);

$\mathrm{M}_{\mathrm{j}}(\mathrm{kg})$ : average tonnage of fuel $\mathrm{j}$ transported on each trip;

$\mathrm{d}_{\mathrm{j}}(\mathrm{km})$ : average distance on which the $\mathrm{M}_{\mathrm{j}}$ mass is transported;

$\mathrm{L}(1 / \mathrm{km})$ : average amount of diesel consumed per $100 \mathrm{~km}$;

$\mathrm{R}$ : average road passability index;

$\mathrm{F}_{\mathrm{g}}(\mathrm{kg} / \mathrm{l}$ of diesel): amount of gas $\mathrm{g}$ emitted by the combustion of one liter of diesel.

\section{Indoor Air Pollution (IAP)}

At an aggregate level, environmental effects come in two forms [6]: indoor air pollution and climate change; in other words, local effects on human health for the first, and global effects on climate for the latter. We cite below the main gases responsible for these two pollutions, which we consider for this study:

- For IAP : particle matter $\left(\mathrm{PM}_{2.5}, \mathrm{PM}_{10}\right)$, Nitrogen Oxide $\left(\mathrm{NO}_{\mathrm{x}}\right)$, Carbon Monoxide $(\mathrm{CO})$ and NMVOC;

- For climate change, the three main GHGs are Carbon Dioxide $\left(\mathrm{CO}_{2}\right)$, Methane $\left(\mathrm{CH}_{4}\right)$ and Nitrous oxide $\left(\mathrm{N}_{2} \mathrm{O}\right)$. 
From literature, for each unit mass of burnt fuel, the amounts of pollutants emitted are given in the following table.

Table 2: Gas emission factor of each fuel during combustion (in $\mathrm{g} / \mathrm{kg}$ of fuel)

\begin{tabular}{|l|r|r|r|r|r|r|r|}
\hline \multicolumn{1}{|c|}{ Gas } & \multicolumn{1}{c|}{$\mathbf{C O}_{\mathbf{2}}$} & $\mathbf{C H}_{\mathbf{4}}$ & $\mathbf{N}_{\mathbf{2}} \mathbf{O}^{*}$ & $\mathbf{N O}_{\mathbf{x}}$ & \multicolumn{1}{c|}{$\mathbf{C O}$} & NMVOC & Particles \\
\hline Fuelwood & $1,605.3$ & 9,78 & 0,07 & 0,08 & 55,80 & 8,88 & $6.35^{* *}$ \\
\hline Charcoal & $2,610.9$ & 11,40 & 0,03 & 0,23 & 194,60 & 6,20 & 2,40 \\
\hline LPG & 5,06 & 1,00 & 0,09 & & $16^{* *}$ & $154^{* *}$ & $89^{* *}$ \\
\hline
\end{tabular}

As far as IAP is concerned, it is mainly the combustion of aerosols that has an impact on the health of people preparing meals indoor. Suspended inside the cooking site, these aerosols undergo physical processes, such as condensation of gaseous species, evaporation of some components, clotting with other particles, and also chemical reactions both internal and external to the particles [7]. According to Nenmar et al. (2003), and Berico et al. (1997), the depth of penetration into the respiratory system of the exposed person depends on the size of these particles. Fine particles of less than $2.5 \mu \mathrm{m}$ are the main culprits of public health problems, as their size allow them to reach the bronchioles and pulmonary alveoli. Those between 4 and $10 \mu \mathrm{m}$ reach only the tracheobronchial region [7]. From a chemical point of view, the combustion of aerosols, polycyclic aromatic hydrocarbons, and soluble organic compounds have an inflammatory character. According to Pennise et al. (2009): "The levels of particulate releases emitted by the combustion of solid biomass in households are likely to be ten to fifty times higher than the World Health Organization's prescribed values" (WHO, 2005). To calculate the IAP within the Municipality, we apply the values set out in table 2 to eq. 5 .

\section{RESULTS AND DISCUSSION}

\section{Consumption models}

Findings in this study show that the following exogenous variables are significant of the fuel consumption models: Household Size (HH), Charcoal Price (CHP), Dwelling Ownership (DO), Household Electricity bill (EL), Opinion about LPG price level (OPG), study level attained by the household head (EDU), Frequency of dried Grain Cooking (FGC), Sacked Charcoal purchase (SAC), lectricity bill per Capita (ELC) and Frequency of Meat Cooking (FMC). Each model of $\mathrm{q}_{\mathrm{ij}}$ will be presented in a subsequent paragraph.

Applying eq. (1) to each class of households for each fuel provides the following consumption models.

Class 1 (charcoal-only). The charcoal consumption model for this class is written:

$$
Q_{\text {lcharcoal }}=24.09-1.475 H H-0.013 C H P+0.907 D O \quad\left(\operatorname{adj}-R^{2}=0.3590 ; p<0.001\right)
$$

Households that consume only charcoal decrease their monthly consumption of charcoal by about 13 grams/capita when the charcoal price increases by one ariary (local current, $1 \$ \mathrm{UD} \approx 3,450 \mathrm{Ar}$ ). It is a logical consumer reflex, and since charcoal is considered as a commodity, this confirms the low value of price elasticity of charcoal consumption. Its consumption per capita is a decreasing function of the variable household size. The decrease is $1.475 \mathrm{~kg} / \mathrm{month}$ for one more individual. Families that own the house where they live consume $0.9 \mathrm{~kg} /$ capita of charcoal more than tenants.

- Class 2 (charcoal-fuelwood). The model is :

$$
Q_{2 \text { charcoal }}=12.968-1.025 H H+0.059 E L \quad\left(\text { adj }-R^{2}=0.2234 ; p<0.01\right)
$$

Charcoal consumption in this class is an increasing function of the electricity bill. For 1,000 Ar/month increase in the electricity bill, the charcoal consumption rises $59 \mathrm{~g} /$ capita/month. Perhaps this variation is low, but assuming that the amount of the electricity bill is directly correlated with the household standard of living, its positive sign shows that the higher the income, the more a household tends to consume more charcoal. On average, the income of this class did not reach the threshold, above which there is fuel switching [8-9] (a jump to class 3 for example), otherwise, the coefficient would be in negative sign. In terms of household size, like in Class 1, one more individual in the family leads to a decrease in the amount of charcoal per capita consumption. This is also vérified in other classes.

As for fuelwood model:

$$
Q_{\text {2fielwood }}=41.720-3.735 H H-4.855 O P G \quad\left(\text { adj- } R^{2}=0.3259 ; p<0.001\right)
$$

The household size variable has the same consequences as for charcoal model, but in this case its effect is higher (3.735 $\mathrm{kg} /$ capita/month). In the same idea, the fact that a household thinks LPG is expensive, its fuelwood consumption decreases by $4.855 \mathrm{~kg} / \mathrm{capita} / \mathrm{month}$ compared to other households that do not have the same opinion. It seems illogical, but these former groups of households recover the decrease in fuelwood consumption through the use of charcoal.

- $\quad$ Class 3 (charcoal-LPG). Combining charcoal and LPG, the charcoal consumption model is:

$$
Q_{3 \text { charcoal }}=52.044-2.44 H H-0.047 \mathrm{CHP} \quad\left(\text { adj- } R^{2}=0.4354 ; p<0.01\right)
$$

For this class, charcoal per capita consumption is a decreasing function of the charcoal price like for other classes. Thus, an increase of one ariary in the charcoal price causes a decrease of $47 \mathrm{~g} / \mathrm{capita} / \mathrm{month}$ of charcoal consumed. As for household size variable, the charcoal consumption decreases by $2.44 \mathrm{~kg} / \mathrm{capita} / \mathrm{month}$ when an individual is added to the family. For a household of five, this equates to about $12 \mathrm{~kg} /$ month less charcoal consumed or 7,000 Ar/month of savings. For LPG consumption of this class:

$$
Q_{3 L P G}=0.770-0.142 H H+0.554 D O+0.501 E D U-0.060 F G C \quad\left(\text { adj- } R^{2}=0.4248 ; p<0.1\right) \quad(11)
$$

Household size has the same effects as for the charcoal model. The decrease in LPG consumed, $60 \mathrm{~g} / \mathrm{capita} / \mathrm{month}$, is also noted if the frequency of dried grain cooking increases by one day. While, being a homeowner, or having a university degree for household head, causes an average increase of about $0.5 \mathrm{~kg}$ of LPG /capita/month. These last two variables are 
among the factors that define the standard of living. Thus, it is quite normal for a higher standard of living to use more frequently a more efficient energy source, LPG for this class.

- $\quad$ Class 4 (charcoal-electricity). For this class :

$$
Q_{4 \text { charcoal }}=44.913-1.191 H H-0.043 C H P-6.352 S A C+0.149 E L C \quad\left(\operatorname{adj}-R^{2}=0.4318 ; p<0.001\right)(12)
$$

Household size, charcoal price, and sack purchased of charcoal lead to a decrease in charcoal per capita consumption. The household size effect is normal with a decrease of $1.191 \mathrm{~kg}$ of charcoal/capita/month. Buying sacked charcoal rather in retail is an advantage for well-off families. The savings are $3.600 \mathrm{Ar}$ for every sack purchased. While each ariary of increase in the amount of electricity bill per individual increases by $149 \mathrm{~g} / \mathrm{capita} / \mathrm{month}$ the quantity of charcoal consumption.

- $\quad$ Class 5 (charcoal-LPG-electricity). This class adds electricity to charcoal and LPG.

$$
Q_{5 \text { charcoal }}=9.858-0.919 H H+0.235 F M C \quad\left(\text { adj- } R^{2}=0.3693 ; p<0.01\right) \quad \text { (13) }
$$

Here, household size decreases by $919 \mathrm{~g} /$ capita/month the charcoal consumption. Frequency of meat cooking is a significant variable of charcoal consumption. One more day per month of meat cooking causes an increase of 235 $\mathrm{g} /$ capita/month of charcoal consumption. As for LPG, the model is:

$$
Q_{5 L P G}=0.796-0.082 H H+0.030 F M C \quad\left(\operatorname{adj}-R^{2}=0.3360 ; p<0.001\right)(14)
$$

The model has the same shape as with charcoal, with the same variables. Only the coefficients differ. LPG per capita consumption decreases by 82 grams with household size and increases by 30 grams with the frequency of meat cooking. Comparing these variations, for household size variable, $0.919 \mathrm{~kg}$ decrease in charcoal consumption saves $581 \mathrm{Ar} / \mathrm{month}$, while $410 \mathrm{Ar} / \mathrm{month}$ for 0.082 grams of non-consumed LPG. As for the variable frequency of meat cooking, the increasing expenditure is $150 \mathrm{Ar}$ /month for both fuels. Generally then, for this class, the bigger the family, the more advantageous it is to cook with charcoal than with LPLG.

- Class 6 (charcoal-electricity-fuelwood). The charcoal consumption model is:

$$
Q_{6 \text { charcoal }}=21-0.022 \mathrm{CHP} \quad\left(\text { adj }-R^{2}=0.3082 ; p<0.01\right) \quad \text { (15) }
$$

Interpretations made for previous classes regarding the charcoal price are also valid for this class, here the decrease is 22 $\mathrm{g} /$ capita/month per ariary increase in charcoal price. For fuelwood:

$$
Q_{6 \text { fuel }} \text { wood }=60.445-0.474 E L \quad\left(\text { adj- } R^{2}=0.7028 ; p<0.01\right) \quad(16)
$$

For fuelwood consumption of this class, only the electricity bill variable (in thousands ariary) is significant. Thus, a thousand ariary increase in the electricity bill leads to a decrease of 447 grams/capita/month of fuelwood consumption. This shows that wealthier households want to use less polluting fuels by spending more on electricity which is considered as a positive significant factor of income level [8-9].

- $\quad$ Class 7 (LPG-electricity). For this class, without solid fuels, the LPG consumption model is:

$$
Q_{7 L P G}=-8.808+0.014 C H P \quad\left(a d j-R^{2}=0.6213 ; p<0.1\right) \quad(17)
$$

Households in this class would increase their LPG per capita consumption by 14 grams if the charcoal price increases by one ariary. This reflects a tendency to prefer LPG to charcoal, i.e. a rise on the energy ladder. For this, some households make a fuel switching, others a fuel stacking [8-9].

Among the consumption models developed in this study, only with $Q_{3 L P G}$ and $Q_{7 L P G}$ that relationships between consumption and variables show statistical significance $\mathrm{p}$-value $<0.1$. For the others, five models have a $\mathrm{p}$-value $<0.01$ and four have a p-value $<0.001$. Therefore, these models can represent household behavior in terms of cooking fuel use in Andranonahoatra.

\section{Analyses of some variables}

\section{Energy consumption per class}

Distributed energy consumption varies enormously from one class to another. To illustrate this, the Figure below reveals a situation worth mentioning. The only two classes 2 and 6 using fuelwood consume much more distributed energy than others.

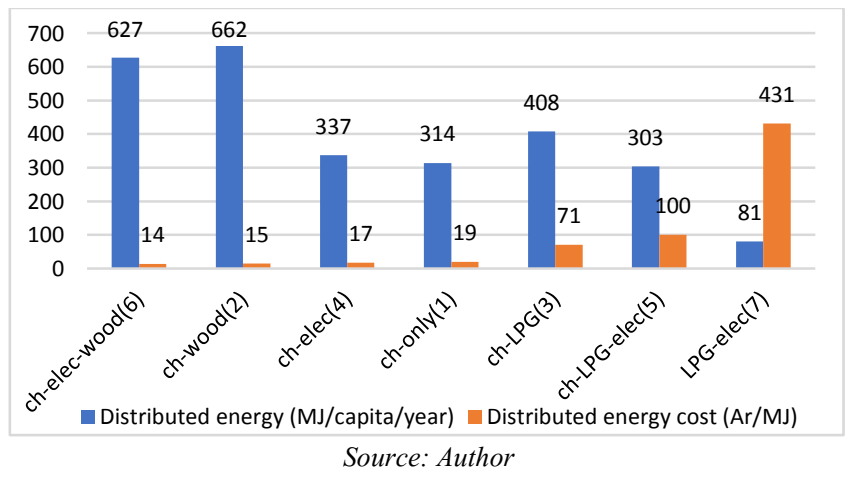

Figure 1: Consumption and distributed energy cost

Figure 1 shows that these two classes consume $662 \mathrm{MJ} /$ capita/month and $627 \mathrm{MJ} /$ capita/month respectively, compared to $81 \mathrm{MJ} /$ capita/month only for Class 7 . Of course, the latter also uses electricity for cooking, but it is also remarkable that 
households cooking with fuelwood pay less the one megajoule distributed, on average 15 ariary versus 85 ariary for classes that combine charcoal and LPG. Households not involved in wood fuels (class 7) pay the highest cost of megajoule, 431 ariary. We can also see that the more households use LPG, the more expensive the megajoule. This cost is even higher if the household adds electricity as a supplement fuel. Overall, Figure 1 shows that the cleaner the fuel, the more expensive the distributed energy. This is an interesting situation because it is part of the energy transition that we are discussing in a later study.

The situation mentioned above deserves to be studied more deeply because using fuelwood is very advantageous by acquiring more energy distributed at the lowest cost. This situation leads many households to prefer fuelwood to other fuels, with some advantages of fuelwood (see Sabuhungu, 2016 and Benard et al. 2015). This "apparent efficiency of fuelwood" conceals, however, two weaknesses in cooking:

- The low efficiency of fuelwood stoves requires more wood than other stoves to cook the same meal;

- The lower heating value of fuelwood requires an even greater amount of wood to provide the amount of heat needed to cook a given meal.

The inseparability of these two characteristics, thus evoking the cost of useful energy, makes fuelwood less competitive, contrary to one might believe. As far as useful energy is concerned, the situation is reversed.

\section{Useful energy cost}

Table 3 below compares the cost of each megajoule of useful energy transferred to the pot.

Table 3: Comparison of useful energy costs (Ar/MJ)

\begin{tabular}{|l|r|r|r|}
\hline \multicolumn{1}{|c|}{ Characteristics } & Fuelwood & Charcoal & LPG \\
\hline Stove efficiency* & $11 \%$ & $23 \%$ & $55 \%$ \\
\hline Lower Heating Value (MJ/kg) & 18 & 32 & 47.30 \\
\hline Average cost** $(\mathrm{Ar} / \mathrm{kg})$ & 200 & 632 & 5,000 \\
\hline Useful energy cost (Ar/MJ) & 101 & 86 & 192 \\
\hline
\end{tabular}

Using the data from Table 3, if the $662 \mathrm{MJ} /$ capita/month of distributed energy consumed by Class 2 (see Figure 1), costing 9,930 Ar, were supplied only by fuelwood, the cost would be about 7,355 Ar; 13,074 Ar with charcoal and 69,679 Ar with LPG. However, when we consider the stove efficiency, Table 3 shows that one megajoule in terms of useful energy is more expensive with fuelwood than with charcoal, $101 \mathrm{Ar} / \mathrm{MJ}$ versus $86 \mathrm{Ar} / \mathrm{MJ}$, that is about $15 \%$ more expensive. Many households in Class 2 (charcoal-fuelwood) do not realize this higher real value of fuelwood cost. Some of those who are aware are blocked by a low-income level. Therefore, generally any household that still uses fuelwood tends to be poorer unless the use of fuelwood is only for ceremonies. In other words, to cook the same meal, these households allocate a higher percentage of their expenditure on cooking fuels compared to other classes. Besides, other drawbacks of fuelwood exist (smoke volume, more space for storage, fewer traders in suburban and urban areas...). In Table 3, the average efficiency of the charcoal stove takes into account the efficiency of improved cookstoves (ICS), about $30 \%$. It should be noted that about $20 \%$ of households in the Municipality still cook with a metal stove, others use both.

In short, most urban households, about $98.4 \%$, cling to charcoal as much as possible (Ralibera et al., 2019), because, in terms of useful energy, it is the cheapest of the three fuels. Hence, Class 1 (charcoal-only) is one of the most energyefficient classes. It buys 86 ariary the megajoule of useful energy. This is not by chance, because apart from this low cost, charcoal has several strengths on the side of urban consumers, making it difficult to substitute. We cite: - cleaner and safer than fuelwood, emits less smoke - easier to store - when lighted, the fire does not need to be maintained - cheaper than other alternative and modern energy sources (LPG and electricity) - sold in almost every corner - sold in retail satisfying household needs and cash (Sabuhungu, 2016).

\section{Household size}

Among the seven classes, only for classes 6 and 7 that the household size variable does not intervene in the consumption models. Given the percentages of households in these two classes who pay more than 100,000 Ar/month of electricity bill (33\% and 50\% respectively), these families can be considered as well-off who care more about quality than quantity. Indeed, for the other five classes, the coefficients of the household size are rather low in LPG consumption models than in fuelwood and charcoal models. So, the cleaner the fuel, the smaller the reduction of per capita consumption due to an increase in household size. In other words, the higher the standard of living of a household, the less the effect of its size on the amount of fuel per capita consumed. In microeconomic terms, the cleaner the fuel, the more inelastic its consumption relative to household size.

\section{Total consumption}

Eq. (7) to (17) first model the total consumption of fuelwood, charcoal, and LPG for all classes; then, by introducing the weight of each class and applying the eq. (2), we obtain the total annual consumption of the Municipality, as following: 1,525 tons of fuelwood, 7,247 tons of charcoal and 40 tons of LPG. Using the heating values, it means a total of 18,217 gigajoules, of which $87.65 \%$ are supplied by charcoal, $11.58 \%$ by fuelwood, and $0.78 \%$ by LPG. These situations lead us 
to try to assess the Municipality's share of pollutant gas emissions for both climate change (global) and indoor air pollution.

\section{Effects on the environment Deforestation}

Using the total consumptions mentioned above applied to equations (3) and (4), deforested areas will be:

- $\quad \mathrm{S}_{\text {fuelwood }}=70 \mathrm{ha} /$ year for the production of fuelwood consumed by the Municipality, taking a commercial volume of $43.5 \mathrm{~m}^{3} /$ ha [8] and a moisture ratio of 1.4. Note that pressure on demand for wood fuel obliges producers to cut wood between the ages of three and four [10].

- $\quad \mathrm{S}_{\text {charcoal }}=2,776 \mathrm{ha} /$ year for the production of charcoal, taking a carbonization efficiency of $12 \%$ in anhydrous wood mass, a commercial volume at four years of age, and a dry wood density of $700 \mathrm{~kg} / \mathrm{m}^{3}$ (World Wide Fund, 2012).

In total, the production of the consumed ligneous fuels requires the cutting of 2,846 hectares/year of forests, or about 440 $\mathrm{m}^{2} /$ capita/year. This is more than double the national average in 2009 , which is $187 \mathrm{~m}^{2} /$ capita/year (Montagne et al., 2009). This high level comes from the significant charcoal consumption in urban areas, needing much more wood in the production phase. According to Ramaroson [11], forests carbon sequestration factor is 28.76 tons of $\mathrm{CO}_{2} / \mathrm{ha} / \mathrm{year}$. Using this value, the households in the Municipality would reduce forest absorption capacity by 81,851 tons of $\mathrm{CO}_{2} / \mathrm{year}$ In other words, prevented sequestration is about 1.266 tons of $\mathrm{CO}_{2} /$ capita/year, as a result of the wood fuel chain.

\section{Pollution during charcoal production}

Using the data in Table 2, the share of the Municipality in the emission of pollutant gases during charcoal production is summarized in the table below.

Table 4: Emitted gas during carbonization ( $t /$ year)

\begin{tabular}{|c|c|c|c|r|r|c|c|c|c|}
\hline Gas & $\mathbf{C O}_{2}$ & $\mathbf{C O}$ & $\mathbf{C H}_{4}$ & $\mathbf{N M V O C}$ & $\mathbf{T S P}$ & $\mathbf{I C P}$ & $\mathbf{N}_{\mathbf{2}} \mathbf{O}$ & $\mathbf{N O}_{\mathbf{x}}$ & Gas+TSP \\
\hline $\begin{array}{c}\text { Total emission } \\
\text { (t/year) }\end{array}$ & 21,936 & 2,413 & 335 & 688 & 247 & 3,681 & 2.174 & 0.942 & 25,617 \\
\hline $\begin{array}{c}\text { Average per } \\
\text { capita } \\
\text { (kg/cap./year) }\end{array}$ & 339 & 37 & 5 & 11 & 4 & 57 & 0.034 & 0.015 & 396 \\
\hline
\end{tabular}

Source: Author

Apart from gases cited in Table 4, species of polycyclic aromatic hydrocarbons (PAHs), which are known to be carcinogenic, are also emitted during charcoal production [7]. The carbonization phase results in the emission of 25,617 t/year of pollutant gases and suspended products, that means $396 \mathrm{~kg}$ of gas/capita/year.

Pollution related to transportation.

Using eq. (6), principal GHG emissions into the atmosphere during fuel transportation are provided by the following table.

Table 5: GHGs emitted during fuel transportation (kg/year)

\begin{tabular}{|c|c|c|c|c|}
\hline Fuel & Fuelwood & Charcoal & LPG & \\
\hline Consumption $\left(\mathrm{Q}_{\mathrm{j}}\right)(\mathrm{kg} /$ year) & $1,524,786$ & $7,246,759$ & 40,036 & \\
\hline Tonnage/trip $\left(\mathrm{M}_{\mathrm{j}}\right)(\mathrm{kg})$ & 5 & 5 & 15 & \\
\hline Average distance $\left(\mathrm{d}_{\mathrm{j}}\right)(\mathrm{km})$ & 72 & 72 & 450 & \\
\hline $\begin{array}{l}\text { Amount of diesel (L) (l/100 } \\
\mathrm{km})\end{array}$ & 10 & 10 & 10 & \\
\hline Road passability index (R) & 1.2 & 1.2 & 1 & Total \\
\hline $\mathrm{CO}_{2}$ & 7,064 & 46,095 & 1,124 & 54,283 \\
\hline $\mathrm{CH}_{4}$ & 0.395 & 1.878 & 0.036 & 2.310 \\
\hline $\mathrm{N}_{2} \mathrm{O}$ & 0.198 & 0.939 & 0.018 & 1.155 \\
\hline
\end{tabular}

Source: Author

According to Andriamifidy (2014b), the studied area is supplied to $70 \%$ of its needs by nearby production areas. We estimate the average distance of $60 \mathrm{~km}$. We also adopt that the remaining $30 \%$ is transported over an average distance of $100 \mathrm{~km}$. We will have, $\mathrm{d}_{\mathrm{j}}=0,7 \times 60+0,3 \times 100=72 \mathrm{~km}$. $\mathrm{R}=1.2$ means that the road condition increases the amount of diesel consumed by $20 \%$. The results in Table 5 are obtained by taking the following values of GHG emitted per liter of diesel consumed: $2,730 \mathrm{~g}$ of $\mathrm{CO}_{2} ; 0.15 \mathrm{~g}$ of $\mathrm{CH}_{4}$ and $0.1 \mathrm{~g}$ of $\mathrm{N}_{2} \mathrm{O}$ [12]. It is assumed that all carbons contained in the diesel are oxidized. The road practicality is different between wood fuels and LPG. Generally, fuelwood and charcoal are produced in an isolated area and then transported on a secondary road before reaching a paved one, including national roads. While LPG is transported on a a tarred road. After calculation, in all, transportation of cooking fuels consumed by the Municipality emits annually about 54,3 tons of $\mathrm{CO}_{2} ; 2.3 \mathrm{~kg}$ of $\mathrm{CH}_{4}$ and $1.2 \mathrm{~kg}$ of $\mathrm{N}_{2} \mathrm{O}$. The emission of the last two GHGs is negligible, but their effects are not the least, because once in the atmosphere their residence time in the 
atmosphere can be very long. Indeed, it takes about 100 years to evacuate $\mathrm{CO}_{2}, 12$ years for methane, and 120 years for $\mathrm{N}_{2} \mathrm{O}$ [13].

\section{Indoor air pollution}

The burning of ligneous fuels during food cooking causes health problems for family members, especially for mothers and those who prepare meals directly near the stoves. Because of a lack of data on the residence time of pollutant gases inside the home, our study considers one person per household directly exposed to smokes during cooking time. From the results of household surveys, $84 \%$ of them cook indoor with charcoal stoves [14]. Using the amount of GHGs emitted during the cooking of one kilogram of fuel (see Table 2), we have the total emission values in the Municipality in Table 6.

Table 6: Amount of indoor air pollutant gases ( $t$ /year)

\begin{tabular}{|c|c|c|c|c|c|c|c|c|}
\hline Fuel & $\begin{array}{c}\text { Quantity } \\
\text { (t) }\end{array}$ & $\mathrm{CO}_{2}$ & $\mathrm{CH}_{4}$ & $\mathrm{~N}_{2} \mathrm{O}$ & $\mathrm{NO}_{\mathrm{x}}$ & $\mathrm{CO}$ & NMVOC & $\mathrm{PM}<10 \mu \mathrm{m}$ \\
\hline Fuelwood & 1,525 & $2,447.7$ & 14.912 & 0.110 & 0.125 & 85.083 & 13.540 & 9.682 \\
\hline Charcoal & 7,247 & $18,920.5$ & 82.613 & 0.232 & 1.667 & $1,410.219$ & 44.930 & 17.392 \\
\hline LPG & 40 & 202.4 & 0.040 & 0.004 & - & 0.641 & 6.166 & 3.563 \\
\hline \multicolumn{2}{|c|}{ Total } & 21,571 & 98 & 0.3 & 2 & 1,496 & 65 & 31 \\
\hline
\end{tabular}

From Table 6, one can calculates that the person who prepares the meal in each household is daily exposed to $6.247 \mathrm{~kg}$ of $\mathrm{CO}_{2}, 28 \mathrm{~g}$ of $\mathrm{CH}_{4}, 0.100 \mathrm{~g}$ of $\mathrm{N}_{2} \mathrm{O}, 433 \mathrm{~g}$ of $\mathrm{CO}, 0.519 \mathrm{~g}$ of $\mathrm{NO}_{\mathrm{x}}$ and $19 \mathrm{~g}$ of NMVOC. Although fine particles of less than $10 \mu \mathrm{m}$ represent only $31 \mathrm{~kg}$, they are more dangerous to human health [15]. According to the World Bank (2009), a complete transition from wood to charcoal would reduce particle health problems by $65 \%$, although traditional charcoal stoves emit even more carbon monoxide (Maes and Verbist, 2012). Another World Bank report declares that indoor air pollution in developing countries is one of the four most critical global environmental problems. Despite this situation in developing countries, the net impact of terrestrial aerosols on the global climate is a cooling [16].

\section{Total emissions}

By summing up the quantities of pollutant gas emitted during the three phases of the cooking fuel chain, we obtain a total of 49,6 t of gas/year. Taken back per capita, the average values in the Municipality are about $0.8 \mathrm{t} / \mathrm{capita} / \mathrm{year}$, of which $95 \%$ is $\mathrm{CO}_{2} ; 9 \mathrm{~kg}$ of $\mathrm{CH}_{4} /$ capita/year, $26 \mathrm{~kg}$ of NMVOC/capita/year and $7 \mathrm{~g}$ of $\mathrm{N}_{2} \mathrm{O} /$ capita/year. For Madagascar, average $\mathrm{CO}_{2}$ emissions are $0.17 \mathrm{t} / \mathrm{capita} /$ year (Global Carbon Atlas, 2019). The per capita emissions of the Municipality seem huge, more than four times the national average. But, charcoal is the most widely used fuel by city dwellers, leading to this very high emission value of $\mathrm{CO}_{2}$. At the same time, in terms of indoor air pollution, the effect on human health of carbon monoxides and fine and ultrafine particles cannot be overlooked. About $3.42 \mathrm{~kg} / \mathrm{capita} / \mathrm{year}$ of these particles is directly inhaled by the person cooking indoor. They are about 9,050 individuals to inhale these particles.

Using the "Global Warming Potential (GWP)" of each gas given by the literature (IPCC, 1990; Dufresne, 2009), we have the $\mathrm{CO}_{2}$-related GWPs of the major GHGs emitted by population in the Municipality at 20 and 100 years, as the following table :

Table 7: Total GHGs in $\mathrm{CO}_{2}$-equivalent $(\mathrm{t} /$ year)

\begin{tabular}{|c|c|c|c|c|c|}
\hline & GHG & $\mathrm{CO}_{2}$ & $\mathrm{CH}_{4}$ & $\mathrm{~N}_{2} \mathrm{O}$ & \multirow{2}{*}{ Total } \\
\hline \multicolumn{2}{|c|}{ Emitted quantity (t/year) } & 50,381 & 586 & 0.432 & \\
\hline \multirow{3}{*}{$\begin{array}{c}\text { After } \\
20 \text { years }\end{array}$} & Remaining quantity & 28,336 & 111 & 0.432 & \\
\hline & $\mathrm{GWP}_{20}{ }^{*}$ & 1 & $86^{* *}$ & 266 & \\
\hline & $\mathrm{CO}_{2}$-eq emission & 28,336 & 9,520 & 115 & 58,500 \\
\hline \multirow{3}{*}{$\begin{array}{c}\text { After } \\
100 \text { years }\end{array}$} & Remaining quantity & 18,327 & 0.141 & 0.432 & \\
\hline & $\mathrm{GWP}_{100^{*}}$ & 1 & $32^{* *}$ & 281.5 & \\
\hline & $\mathrm{CO}_{2}$-eq emission & 18,327 & 5 & 122 & 25,450 \\
\hline
\end{tabular}

Using the Forster et al. model for $\mathrm{CO}_{2}$ and $\mathrm{CH}_{4}$, Table 7 displays that in 20 years, the GHGs emitted today will produce the effect of the equivalent of 58,500 tons of $\mathrm{CO}_{2}\left(\mathrm{CO}\right.$ transformed into $\left.\mathrm{CO}_{2}\right)$, over the same period. The emission will still be 25,450 tons of $\mathrm{CO}_{2}$-eq after 100 years. Taking only the $\mathrm{CO}_{2}$, its punctual emission estimated at 0.6 t/capita is far higher than the national average, $0.1 \mathrm{t}$ /capita (Statistical Yearbook, 2013). As we have already seen before, this higher level is still based on the fact of "charcoal urban fuel". It confirms the $10 \mathrm{~kg}$ of $\mathrm{CO}_{2} / \mathrm{kg}$ of produced charcoal during carbonization, which is not far from the values reported by FAO [18], 5.7 to $9 \mathrm{~kg} \mathrm{CO}$-eq/ $/ \mathrm{kg}$ of charcoal produced. From Table 7, one can calculate that in 20 years, each citizen of the Municipality will emit about 1.1 tons $\mathrm{CO}_{2}$-eq/year due to the household cooking fuel use. Arguably, this value is in the scale of 2.65 tons $\mathrm{CO}_{2}$-eq/year assessed by USAID (2011) across all sectors, and less than 5 tons $\mathrm{CO}_{2}$-eq/year for African countries (Institute for Climate Economics, 2019). 
However, it should be noted that the carbon intensity of GDP (Growth of Domestic Product) is four times higher in Africa than in the European Union, which means that four times as many GHGs are emitted per unit of wealth produced [19].

\section{CONCLUSION}

This study shows us the importance of household size, charcoal price, and electricity bill in household fuel consumption models. It also brings up the rank of socio-economic factors, such as the education level attained by the household head, homeownership, and plate habits, in the cooking fuel consumption. The use of ligneous fuel has a direct impact on forest resources, on indoor air quality and on global climate.

Recommendations for short and long terms are to be made to ensure the supply of household fuels and also to preserve the ecosystem. Actions on exogenous factors can be implemented at each phase of the fuel chain. - For the production phase, reforestation using a rapidly growing type of tree is necessary to ensure that resource productivity is always able to keep up with demand. Modernization and improvement of the charcoal kilns efficiency, with the increase in capacity of charcoal miners, are also decisive factors. In this sense, projects to produce charcoal briquette from plant waste must also be encouraged and financed. - It is important to choose the right place for reforestation projects to avoid an unnecessary increase in transportation costs. - New regulations concerning fiscality are also needed for charcoal retailers. - For the substitution of charcoal for LPG, make LPG closer to consumers and accessible to all income levels with small and medium-sized cylinders. This, while avoiding supply disruptions from outside. A tax policy encouraging the adoption of alternative fuels is also an element of strategy to be considered. - As for the end-use, the efficiency of the cooking stove plays a major role in the solid fuel economy. For charcoal, it is important to push even more the spread of standard ICS, because even though the vast majority of households have a so-called ICS, most of them are bought cheaply from unlicensed manufacturers and many do not meet the required technical standards. - As for the cooking place, awareness programs are needed to encourage and to sensitize households to ensure the ventilation of the site. - In a socio-economic field, controlling the demography and development program aiming to increase household income have a beneficial and lasting effect on the residential energy sector. Although these two factors are only exogenous in the medium and long terms, programs must still be initiated and supported from now on. Briefly, the government should continuously study various multi-sector scenarios to develop well-adapted strategies to mitigate or even curb the negative impacts of the use of household cooking fuels and to protect the environment.

\section{Conflict of interest: None}

\section{REFERENCES}

1. Institut National de la Statistique (2013), "Enquête INSTAT/ENSOMD, 2012-2013, ” Madagascar.

2. Ralibera, A. G., Andrianaivoravelona, J. O., Rakotosaona, R. and Ramaroson J. D., (2019), "Analysis of Household Cooking Fuel Choice in the Municipality of Andranonahoatra, Madagascar," International Journal of Progressive Sciences and Technologies (IJPSAT), ISSN: 2509-0119, Vol. 16 No 1, pages 160-168.

3. Bisu, D. Y., Kuhe, A., and Iortyer, H. A., (2016), "Urban household cooking energy choice: an example of Bauchi metropolis, Nigeria,". Energy, Sustainability and Society.

4. Muller, C. and Yan, H., (2018), "Household Fuel Use in Developing Countries: Review of Theory and Evidence," Energy Economics, Elsevier, 70, pages 429 - 439.

5. Déglise, X., (1982), "Les Conversions Thermochimiques du Bois," R.F.F. XXXIV-4.

6. AirParif Actualité, (2009), $N^{\circ} 33$.

7. Assamoi, A. Y. E-M. (2011), "Emissions anthropiques d'aérosols carbonés en Afrique en 2005 et en 2030 : élaboration d'inventaires et évaluation," Thèse, Université Toulouse III - Paul Sabatier, Discipline ou spécialité : Physique-Chimie de l'Atmosphère.

8. Masera, O. R., Saatkamp, B. D. and Kammen, D. M., (2000), "From linear fuel switching to multiple cooking strategies: A critique and alternative to the energy ladder model," World Development, Vol. 28, $N^{\circ} 12$, pages 2083-2103.

9. Van der Kroon, B., Brouwer, R. and Van Beukering, P., (2013), "The energy ladder: Theoretical myth or empirical truth? Results from a meta-analysis. Chapter two," Renewable and Sustainable Energy Reviews, 20, pages 504-513.

10. Verhaegen, D., Randrianjafy, H., Andriatsitohaina, R. H., Rakotonirina, M-C. T., Andriamampianina, N., Montagne, P., Rasamindisa, A., Chaix, G., Bouillet, J-P. and Bouvet, J-M., (2014) "Eucalyptus robusta pour une production durable de bois énergie à Madagascar : bilan des connaissances et perspectives, ” Bois et forêts des tropiques, Eucalyptus Robusta, , $n^{\circ}$ 320 (2).

11. Ramaroson, J. de D., (2010), "Etude de la transformation du charbon de terre de la Sakoa en combustible domestique," Thèse de doctorat, Ecole Supérieure Polytechnique d'Antananarivo, Université d'Antananarivo.

12. Ministère de l'Environnement, Canada, (2017), "Rapport d'inventaire national - 2 Partie".

13. Jancovici, J-M., (2017), "Gas et cycle du carbone".

14. Edwards, R., Princevac M., Weltman, R., Ghasemian, M., Arora, N. K., Bond T., (2017), "Modelling emission rates and exposures from outdoor cooking," Atmospheric Environment, pages 50-60.

15. World Health Organisation, (2004), "Indoor air quality guidelines on household fuel combustion: Strategy implications of new evidence on interventions and exposure-risk functions". 
ISSN (Online): 2455-3662

EPRA International Journal of Multidisciplinary Research (IJMR) - Peer Reviewed Journal

Volume: 6 | Issue: 5 | May 2020 || Journal DOI: 10.36713/epra2013 || SJIF Impact Factor: 7.032 ||ISI Value: 1.188

16. Sottile, M-F., (2011), "L'influence des changements climatiques sur la qualité de l'air," Produit par Ouranos pour le Ministère du Développement durable, de l'Environnement et des Parcs du Québec.

17. Dufresne, J-L., (2009), "L'utilisation du potentiel de réchauffement global pour comparer les émissions de méthane et de CO2, " Laboratoire de Météorologie Dynamique, Institut Pierre Simon Laplace. CNRS, $n^{\circ} 64$, pages 54-58.

18. FAO, (2017), "The charcoal transition. Greening the charcoal value chain to mitigate climate change and improve local livelihoods".

19. Institute for Climate Economics (I4CE), (2019), "Chiffres clés du climat France, Europe et Monde," Ministère de la Transition Ecologique et Solidaire, Commissariat général au développement durable.

20. Serrano-Medrano, M., Arias-Chalico, T., Ghilardi, A., Masera, O., (2013), "Spatial and temporal projection of fuelwood and charcoal consumption in Mexico,” Energy Sustainable Development, http://dx.doi.org/10.1016/j.esd.2013.11.007. 